
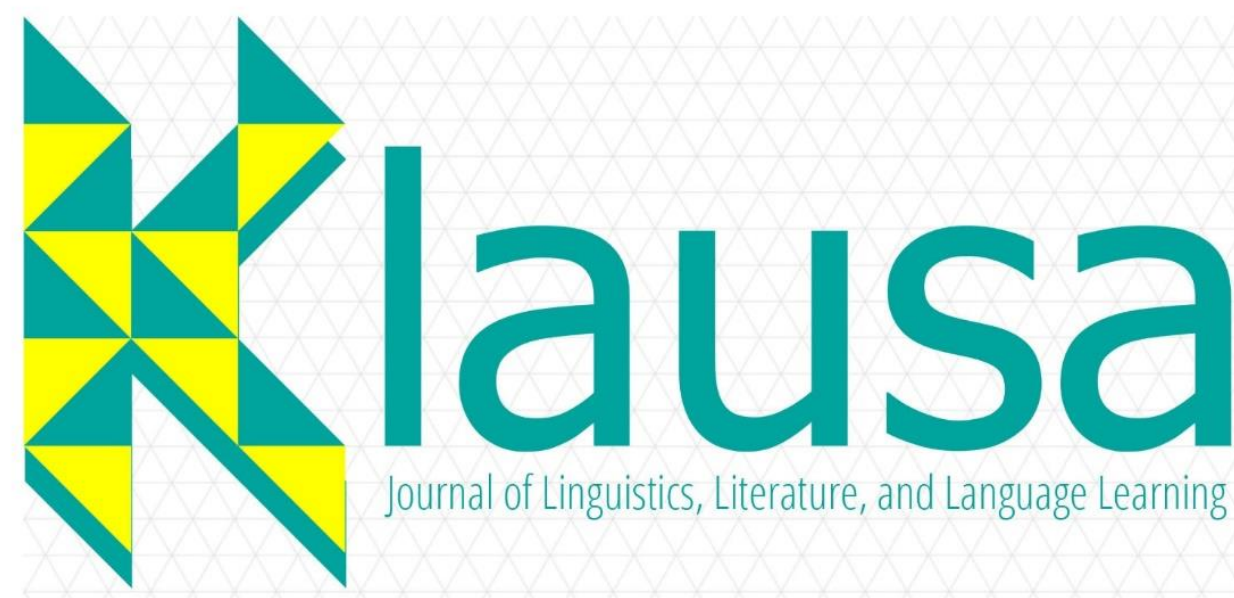

ISNN 2620-9527 Volume 04 Nomor 02

Journal of Linguistics, Literature, and Language Learning

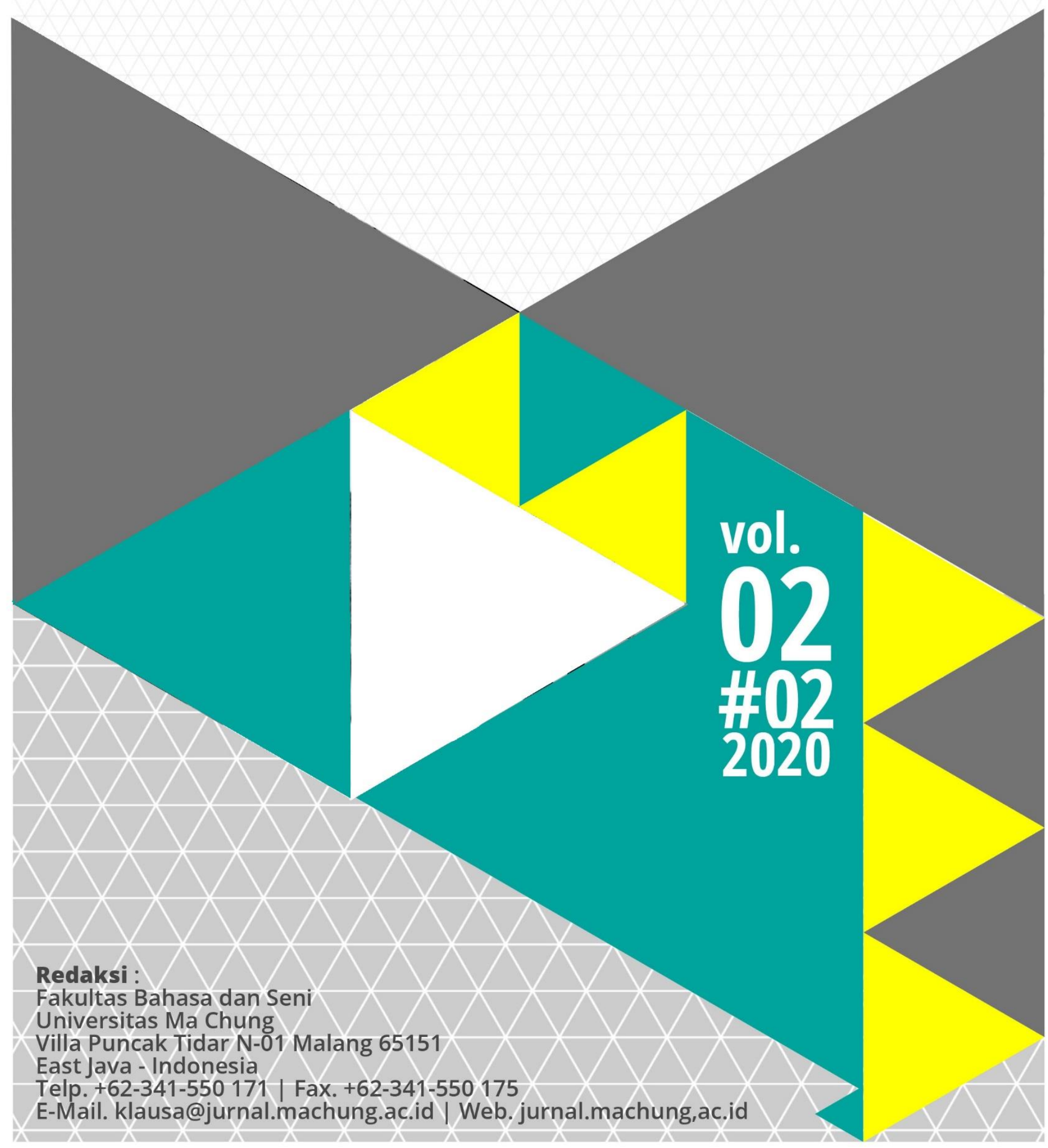


ISSN: $2301-4822(p)$

DOI: $\quad 10.33479 /$ klausa.v4i02

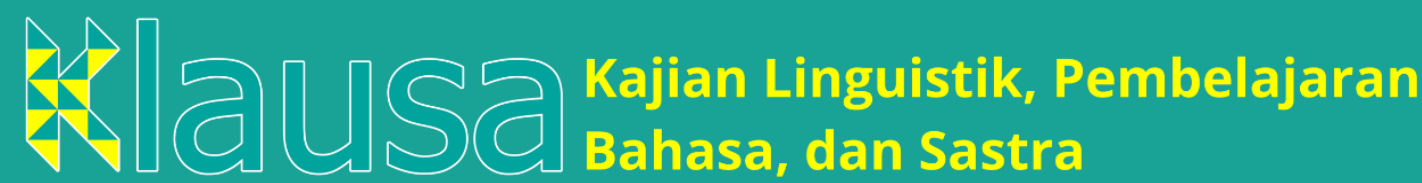

\section{Editorial Team}

\section{Editor-in-Chief}

Journal Manager

Editors

Reviewers

Publisher

Address

Frequency
: $\quad$ Dr. Daniel Ginting

: Wawan Eko Yulianto, Ph.D.

: Prof. Dr. Patrisius I. Djiwandono

Lilis Lestari Wilujeng, M.Hum.

: F.X Dono Sunardi, M.A.

Dhatu Sitaresmi, MTCSOL.

Anggrah Diah Arlinda, MTCSOL.

Yohanna Nirmalasari, S.Pd., M.Pd.

Prof. A. Effendi Kadarisman, Ph.D.

Sisilia Halim, Ph.D.

Dr. Mundi Rahayu

Dr. Ross Wood

Dr. Leticia Araceli Salas Serrano

: Faculty of Language and Arts

Universitsas Ma Chung

: The Faculty of Language and Arts

Ma Chung University

Villa Puncak Tidar N-01 (65151)

Malang, East Java, Indonesia

Email: jurnal.klausa@machung.ac.id

: Twice a year 


\section{CONTENTS}

FOREWORD

iii

(RETRACTED)_PRESUPPOSITION IN THE GUARDIAN NEWS

STORIES: A PRAGMATIC ANALYSIS

Crisnova Katalonika Siahaan ${ }^{1}$, Zia Hisni Mubarak ${ }^{2}$.

FLOUTING MAXIMS IN WHITE HOUSE DOWN

Rebekka Sinaga $^{1}$, Nurma Dhona Handayani ${ }^{2}$ 81

WORD FORMATION IN SHARENA DELON'S INSTAGRAM POSTS: A MORPHOLOGICAL ANALYSIS

Crisnova Katalonika Siahaan¹, Zia Hisni Mubarak² .89

(RETRACTED)_MAXIMS IN JOHN GREEN'S THE FAULT IN OUR STARS: a PRAGMATIC ANALYSIS

Sasmi Saragih $^{1}$, Ambalegin $^{2}$

PENERAPAN CONTENT AND LANGUAGE INTEGRATED LEARNING

(CLIL) PADA PELAJARAN MATEMATIKA DI TINGKAT

PENDIDIKAN DASAR DI INDONESIA

Bebasari Amiroh ${ }^{1}$, Cindy Fortunasari ${ }^{2}$, Daniel Ginting ${ }^{3}$

ANALISIS KUALITAS TERJEMAHAN TEKS BAHASA JEPANG KE

BAHASA INDONESIA DENGAN BING TRANSLATOR

Wisnu Setya Budi ${ }^{1}$, Febi Ariani Saragih ${ }^{2}$

中印姓名比较研究

Anggrah Diah Airlinda ${ }^{1}$

印尼留学生汉语撮口呼韵母偏误分析

Dhatu Sitaresmi ${ }^{1}$ 155 


\title{
PENERAPAN CONTENT AND LANGUAGE INTEGRATED LEARNING (CLIL) PADA PELAJARAN MATEMATIKA DI TINGKAT PENDIDIKAN DASAR DI INDONESIA
}

\author{
Bebasari Amiroh ${ }^{1}$, Cindy Fortunasari², Daniel Ginting ${ }^{3}$ \\ ${ }^{1}$ Universitas Ma Chung (211710003@student.machung.ac.id) \\ ${ }^{2}$ Universitas Ma Chung (211810007@student.machung.ac.id) \\ ${ }^{3}$ Universitas Ma Chung (daniel.ginting@ machung.ac.id)
}

\begin{abstract}
ABSTRAK
This article aims to describe the fitness of Content and Language Integrated Learning (CLIL) in Mathematics subject for elementary education in Indonesia. The research was a qualitative study conducted through a case study. The case study was conducted in the context of elementary education. This research discovered that CLIL needed to be conducted in consideration of the urgency of teaching Mathematics in English, the appropriate method of teaching Mathematics in English, the appropriate duration of applying CLIL, and the impacts of CLIL on learners. Through the application of CLIL in teaching Mathematics in English, Indonesian students will be accustomed to the concept of understanding word problems in English, be accustomed to the application of higher order thinking in solving math problems, have higher interest in math and English, and have a stronger foundation for a more complex math learning at a higher level.
\end{abstract}

Keywords: mathematic literacy, Content and Language Integrated Learning (CLIL), mathematics learning in English

\section{PENDAHULUAN}

Dengan semakin berkembangnya teknologi dan menguatnya globalisasi, sangatlah penting bagi pelajar di Indonesia untuk meningkatkan kompetensi diri. Literasi matematika adalah salah satu keahlian yang penting untuk dipahami dan dikuasai oleh para pelajar. Sayangnya, tingkat literasi matematika di kalangan pelajar Indonesia saat ini masihlah rendah (Mahdiansyah \& Rahmawati, 2014). Hasil tes Programme for International Student Assessment atau yang disingkat dengan PISA untuk tahun 2018 menunjukkan bahwa Indonesia menduduki peringkat 73 dari 78 negara di bidang literasi matematika (OECD, 2019). Rata-rata skor PISA untuk literasi matematika Indonesia juga masih jauh di bawah ratarata OECD (OECD, 2019). Hal ini menunjukkan bahwa pelajar Indonesia membutuhkan pelatihan pemahaman literasi matematika dasar. Selain itu, kumpulan soal literasi matematika pada tes internasional umumnya menggunakan Bahasa Inggris sebagai bahasa pengantar. Penulis berpendapat bahwa siswa membutuhkan pondasi literasi matematika dengan metode 
pengajaran yang memasukkan Bahasa Inggris ke dalamnya. Pengajaran matematika dalam Bahasa Inggris perlu dimulai dari tingkat dasar, yaitu tingkat sekolah dasar karena usia pelajar di tingkat tersebut merupakan usia prima di mana siswa dapat menyerap pengajaran bahasa dengan baik (Ferreira \& Morrison, 1994) dan dapat memahami pengajaran interdisipliner (Piaget, 2003).

Content and Language Integrated Learning (CLIL) merupakan metode yang menggabungkan mata pelajaran sekolah dengan menggunakan bahasa asing (Lasagabaster, 2008). Metode CLIL telah diterapkan dalam sistem pendidikan negara Eropa seperti Finlandia, Jerman, Belanda, dan Belgia semenjak tahun 1990 (Marsh, 2002). Metode ini dikembangkan oleh David Marsh dan memiliki manfaat ganda yaitu menguatkan pemahaman siswa terhadap mata pelajaran yang diajarkan, serta pemahaman bahasa asing yang diterapkan (Marsh, 2002). Metode CLIL juga memiliki prinsip penggunaan higher-order thinking (Collins, 2014) yang selaras dengan prinsip literasi matematika (Dinni, 2018). Metode CLIL terbukti dapat meningkatkan kesadaran metalinguistik (Surmont, 2016), meningkatkan motivasi siswa di bidang yang dipelajari (Lasagabaster, 2008) dan meningkatkan performa matematika siswa (Lasagabaster, 2008, Surmont, 2016). Berdasarkan latar belakang ini, tulisan ini bertujuan untuk mendeskripsikan kelayakan metode CLIL dalam mata pelajaran matematika pada jenjang pendidikan sekolah dasar.

\section{KAJIAN PUSTAKA}

Content and Language Integrated Learning adalah metode pengajaran immersionbased dimana dalam pengajarannya mempelajari mata pelajaran tertentu dengan menggunakan bahasa asing (Marsh, 2002) dan telah banyak diterapkan di negara-negara Eropa seperti Finlandia, Jerman, Belgia, dan Belanda (Marsh, 2013). Banyak penilitian yang telah membuktikan manfaat dari CLIL, dan ini bisa menjadi sebuah hasil dari pembelajaran berbasis konteks. Siswa di kelas CLIL akan secara langsung dihadapkan pada target language sembari mempelajari makna konteks (contoh, matematika). Dengan demikian, siswa secara otentik menggunakan bahasa untuk memahami konteks dari mata pelajaran tersebut, dan tidak terlalu tertekan untuk menggunakan target language dengan benar. Ketakutan menggunakan target language akan berkurang secara berangsur, dan dengan demikian siswa CLIL dapat lebih banyak mempraktikkan target language dibandingkan ketika mereka berada di kelas bahasa secara tradisional. Selain itu, interaksi dengan guru juga lebih intensif dibandingkan dengan kelas non-CLIL (Nikula, 2010).

Dalam studi yang dilakukan oleh Rumlich dan Grum (2012), akurasi pelajar CLIL dalam teks tertulis secara signifikan lebih tinggi dibandingkan pelajar non-CLIL. Grum menganalisis data mengenai kemampuan peserta didik untuk menanggapi tugas komunikatif lisan yang kompleks dari 90 sampel peserta didik dari CLIL dan kelas non-CLIL di Berlin. Grum menemukan bahwa pelajar CLIL secara signifikan bekerja lebih baik daripada rekan non-CLIL dalam hal cakupan leksikal dan kefasihan. Fehling (2008) menemukan keunggulan peserta didik CLIL dalam dimensi afektif, yang melihat pada sikap dan keterikatan peserta didik dengan bahasa asing. Prochazkova (2013) dalam studinya menyebutkan bahwa pembelajaran Matematika dalam bahasa asing memberikan perspektif yang berbeda terhadap peserta didik pada area konten tersebut; dapat memperkaya kosa kata yang berbeda yang kemudian menciptakan asosiasi lebih lanjut; dan CLIL menjadi metode untuk pengajaran 
konten melalui bahasa asing, yang dapat memicu pendekatan yang lebih aktif dan pemahaman yang lebih dalam.

\section{METODE PENELITIAN}

Studi ini merupakan studi kualitatif, dan metode penelitian yang digunakan dalam penelitian ini adalah studi kasus. Studi kasus ini dilakukan dalam konteks pendidikan dasar. Sumber data primer berasal dari dua informan kunci yaitu A, seorang ahli dalam bidang pengajaran Bahasa Inggris. Beliau adalah seorang guru besar di sebuah perguruan tinggi di kota Malang. Narasumber kedua adalah B, yaitu seorang praktisi pendidikan di bidang matematika. Beliau sudah bekerja di bidang matematika selama lebih dari 44 tahun. Pengalaman dan keahlian adalah kriteria dari pemilihan kedua narasumber kunci ini.

Interview adalah teknik pengambilan data yang dilakukan dalam studi ini. Data dianalisis dengan mengikuti beberapa tahapan yaitu pengumpulan data, reduksi data, proses pengkodean, dan penarikan kesimpulan. Data sekunder didapatkan dari buku, teori, artikel dan penelitian yang telah dilakukan sebelumnya, serta laporan nilai siswa sekolah dasar yang mengikuti kursus program CLIL di Malang.

\section{TEMUAN DAN PEMBAHASAN}

\section{Temuan}

Pada bagian ini, penulis akan memaparkan temuan penelitian: pentingnya pengajaran matematika dalam Bahasa Inggris, metode pengajaran matematika dalam Bahasa Inggris yang tepat, masa penerapan CLIL yang tepat, serta efek dari CLIL terhadap siswa.

\section{Pentingnya Pengajaran Matematika Dengan Bahasa Inggris}

Narasumber berkesimpulan bahwa pengajaran matematika dalam Bahasa Inggris di sekolah di Indonesia cukup penting supaya dapat meningkatkan daya saing di ranah internasional. Selain itu, narasumber juga mengatakan bahwa pengerjaan matematika dalam Bahasa Inggris dapat meningkatkan kepercayaan diri anak bila ingin mengikuti kompetisi Internasional.

\section{Masa Yang Tepat Untuk Menerapkan Clil}

Narasumber berpendapat bahwa sebaiknya pengajaran dilakukan dimulai di tingkat sekolah dasar, karena siswa di usia sekolah dasar sedang berada di tahap perkembangan kognitif yang optimal dalam pembelajaran bahasa. Narasumber juga mengatakan bahwa sebisa mungkin pengajaran ditanamkan dari SD karena materinya masih dasar, sehingga siswa bisa mendapatkan pondasi yang kuat sebelum melanjutkan ke tingkat SMP yang lebih kompleks.

\section{Metode Pengajaran CLIL Yang Tepat}

Menurut narasumber, penerapan CLIL sebaiknya mengikuti perkembangan jaman, seperti memasukkan unsur teknologi dan permainan game untuk anak-anak, supaya anak-anak tidak merasa bosan. Narasumber berpendapat bahwa matematika merupakan pelajaran yang menakutkan bagi anak-anak, apabila dalam pengajaran bisa disertakan gambar, ilustrasi, dan juga dibuat seperti permainan game, maka narasumber menyimpulkan bahwa hal ini akan cocok untuk usia SD. Penerapan CLIL juga sebaiknya memasukkan soal cerita supaya anakanak belajar logika. Selain itu, jika bisa menggunakan aplikasi game dan permainan akan jauh lebih baik, mengingat pelajar masih anak-anak SD, dan jikalau bisa disesuaikan juga dengan perkembangan jaman supaya dapat mengikuti minat anak-anak. Kurikulum bisa dimulai 
dengan penyebutan angka dan operasinya, aritmetika, bangun datar, serta bangun ruang yang mana siswa SD sudah tahu istilah dalam bahasa Indonesianya.

\section{Urgensi Literasi Matematika Dalam Bahasa Inggris Untuk Kompetisi Dan Tes International}

Narasumber berpendapat bahwa pelatihan literasi matematika dalam Bahasa Inggris cukup diperlukan, mengingat kompetisi Internasional umumnya menggunakan soal-soal dalam Bahasa Inggris. Siswa perlu dibiasakan mengerti soal cerita dalam Bahasa Inggris dan cara memecahkannya secara kritis dan analitis, dimana hal ini perlu diajarkan dimulai dari bangku sekolah dasar. Narasumber juga menambahkan bahwa pengajaran literasi matematika dalam Bahasa Inggris penting terutama bila targetnya ingin mengikuti kompetisi Internasional. Tetapi kembali lagi anak-anak yang mengikuti kompetisi perlu yang memang suka matematika.

\section{Efek Dari Clil}

Narasumber mengatakan bahwa metode CLIL dapat memberikan manfaat ganda bagi siswa SD. Dikarenakan mereka mempelajari matematika dan juga Bahasa Inggris dalam waktu yang bersamaan. Hal ini memberikan pemahaman interdisipliner yang baik untuk anak sekolah dasar, sehingga mereka akan dapat berpikir lebih luas dan memiliki fleksibilitas yang tinggi. Siswa akan lebih terbiasa berpikir kritis dan analitik, yang mana merupakan bentuk higherorder of thinking. Menurut narasumber, dalam jangka panjang, pengajaran matematika dalam Bahasa Inggris semenjak SD dengan metode CLIL memberikan efek positif untuk tes internasional seperti PISA. Narasumber juga merasa bahwa pengajaran matematika dalam Bahasa Inggris dapat memberi efek yang bagus untuk siswa SD. Bila dilakukan dengan tepat dan memasukkan unsur teknologi, anak-anak akan lebih termotivasi dan tertarik dengan matematika. Mereka akan lebih percaya diri, dan siap apabila dikirimkan ke lomba tingkat Internasional, dan lebih siap apabila mereka melanjutkan jenjang pendidikan ke luar negeri.

Berdasarkan hasil laporan siswa dari sebuah program CLIL di Malang, terdapat peningkatan performa dan nilai siswa yang berada di bangku SD. Sebanyak 10 siswa SD yang mengikuti kursus matematika dalam Bahasa Inggris dengan metode CLIL mengalami peningkatan hasil Ulangan Harian (UH) di mata pelajaran matematika dan Bahasa Inggris, serta mendapatkan skor Penilaian Akhir Semester (PAS) di atas 96 untuk pelajaran matematika dan Bahasa Inggris.

Tabel 1.Nilai rata-rata pelajaran matematika dan Bahasa Inggris siswa yang mengikuti program kursus CLIL

\begin{tabular}{|c|c|c|c|c|}
\hline Mata Pelajaran & Kelas & Mean UH 1 & Mean UH 2 & Mean PAS \\
\hline Matematika & 1 & 90 & 92 & 96 \\
\hline Bahasa Inggris & 1 & 86 & 95 & 98 \\
\hline & & & & \\
\hline Mata Pelajaran & Kelas & Mean UH 1 & Mean UH 2 & Mean PAS \\
\hline Matematika & 2 & 90 & 95 & 98 \\
\hline Bahasa Inggris & 2 & 92 & 95 & 98 \\
\hline Mata Pelajaran & & & & Mean PAS \\
\hline Matematika & Kelas & Mean UH 1 & Mean UH 2 & 97 \\
\hline Bahasa Inggris & 3 & 95 & 96 & 96 \\
\hline
\end{tabular}

*Keterangan : Ulangan Harian (UH) dan Penilaian Akhir Semester (PAS). 


\section{Pembahasan}

Penelitian ini menemukan beberapa hal terkait dengan penerapan metode CLIL, yaitu pentingnya penerapan matematika dalam Bahasa Inggris di sekolah Indonesia, masa penerapan CLIL yang tepat, metode pengajaran matematika dan Bahasa Inggris yang tepat, pentingnya literasi matematika dalam Bahasa Inggris untuk performa di ranah Internasional, dan juga efek dari penerapan CLIL. CLIL memiliki efek yang cukup baik dalam peningkatan performa siswa (Lasagabaster, 2008), yang didukung oleh data nilai siswa yang telah mengikuti program kursus CLIL, di mana siswa CLIL mengalami peningkatan nilai di mata pelajaran matematika dan Bahasa Inggris. Hal ini selaras dengan studi yang dilakukan oleh (Surmont, 2016) di Belgia yang menunjukkan bahwa siswa CLIL memiliki peningkatan performa di bidang matematika.

Faktor pertama yang mendukung kelayakan penerapan CLIL adalah faktor kesiapan usia. Jenjang pendidikan yang tepat untuk memulai pengajaran matematika dalam Bahasa Inggris adalah jenjang sekolah dasar. Hal ini dikarenakan pada usia tersebut, siswa sedang berada di tahap perkembangan kognitif yang optimal untuk pembelajaran bahasa dan logika. Hal ini selaras dengan teori perkembangan kognitif (Piaget, 2003) di mana di usia sekolah dasar, siswa sedang mengembangkan kemampuan berpikir logis dan konkret. Penelitian yang dilakukan oleh (Ghazi, 2016) menunjukkan bahwa siswa usia 7-11 tahun dapat mengerjakan persoalan logika dengan baik. Usia pada tahap concrete juga memungkinkan siswa untuk melakukan decenter atau kemampuan untuk fokus ke lebih dari satu hal dalam satu waktu (Piaget, 2003). Usia ini merupakan usia optimal untuk belajar sistem pengukuran, berat benda, volume, perubahan bentuk benda, di mana siswa belajar berdasarkan kehidupan sehari-hari mereka (Kandola, 2019). Hal ini sesuai dengan konsep literasi matematika di mana siswa diberikan persoalan sehari-hari dan perlu memecahkannya secara logis dan konkret (OECD, 2019). Di jenjang SD, materi yang diajarkan masih merupakan materi dasar, sehingga siswa mendapatkan pondasi ilmu dan motivasi yang kuat (Lasagabaster, 2008) sebelum melanjutkan ke jenjang yang lebih tinggi.

Faktor kedua yang mendukung kelayakan penerapan metode ini adalah stimulasi higher-order thinking. Pengajaran CLIL di tahap perkembangan concrete akan melatih siswa untuk berpikir secara analitik, dan belajar mengaktifkan higher-order thinking. Higher-order thinking terwujud di dalam cara anak-anak memecahkan persoalan matematika dengan cara berpikir analitik. Metode pengajaran matematika dalam Bahasa Inggris yang tepat adalah metode CLIL karena CLIL menganut prinsip yang mendorong siswa untuk mampu berpikir kritis, analitis, melatih penggunaan higher-order thinking (Marsh, 2013), berempati, serta meningkatkan kemampuan metalinguistik siswa (Surmont, 2016). Penggunaan higher-order thinking berkesinambungan dengan performa literasi matematika (Collins, 2014, Dinni, 2018).

Faktor ketiga adalah penggunaan teknologi yang terintegrasi ke dalam proses pembelajaran. Penerapan CLIL akan berlangsung dengan baik bila didukung dengan penggunaan teknologi, aplikasi berbasis teknologi, permainan atau gamification. Hal ini didukung oleh penelitian (Wakil, Qaisar, \& Mohammed, 2017) yang menunjukkan bahwa siswa yang menggunakan teknologi di kelas memiliki GPA 20 poin lebih tinggi dibandingkan siswa yang tidak menggunakan teknologi di kelas. Pengajaran juga sebaiknya memasukkan unsur gambar dan ilustrasi ke dalam materi pengajaran. Hal ini selaras dengan teori 
pembelajaran anak yang menyatakan bahwa siswa sekolah dasar belajar lebih baik dengan gambar yang mengilustrasikan hal nyata (Piaget, 2003).

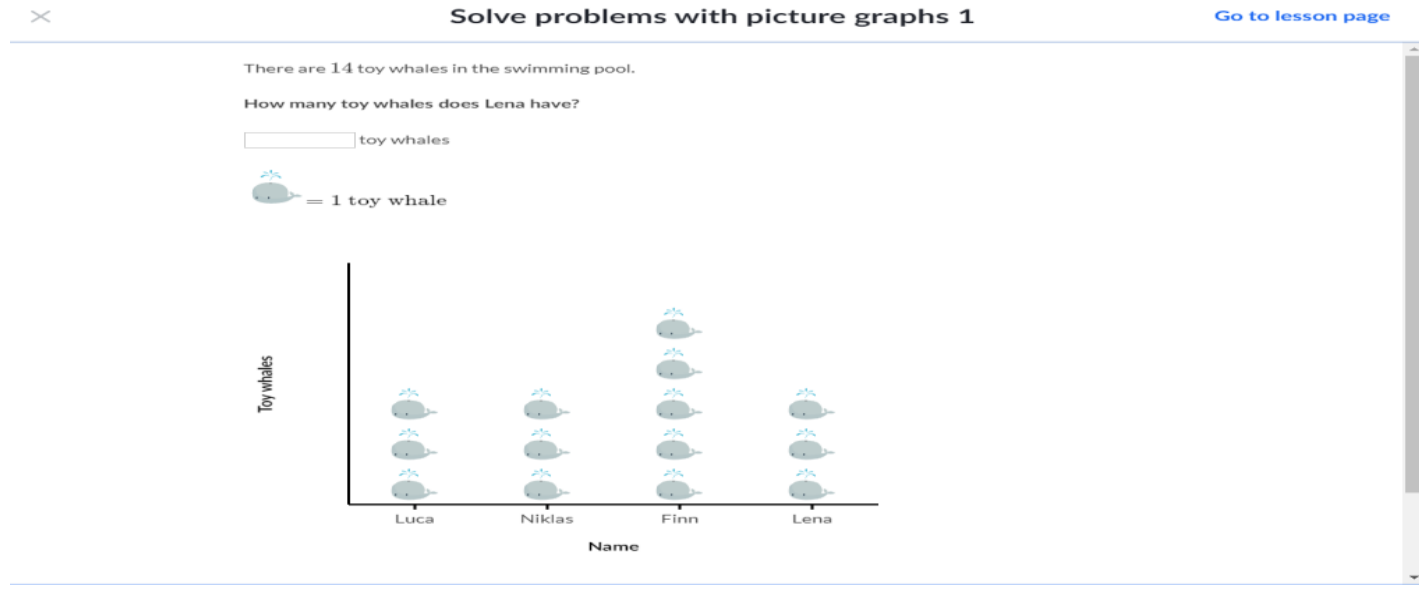

Gambar 1. Contoh soal kelas 2 SD yang diajarkan di program CLIL matematika dalam Bahasa Inggris (sumber gambar dari Khan Academy, 2019).

\section{KESIMPULAN}

Pengajaran matematika dalam Bahasa Inggris dinilai perlu untuk dilakukan. Adapun alasannya adalah supaya daya saing siswa Indonesia di ranah Internasional dapat meningkat. Selain itu, banyak tes literasi matematika yang menggunakan Bahasa Inggris. Menurut narasumber, masa tepat untuk menerapkan metode CLIL dalam pengajaran matematika adalah saat usia sekolah dasar. Hal ini dikarenakan pada usia tersebut, siswa sedang berada di tahap perkembangan kognitif yang optimal untuk pembelajaran bahasa. Penerapan CLIL di tahap sekolah dasar juga disarankan karena pada jenjang SD, materi yang diajarkan masih merupakan materi dasar, sehingga siswa mendapatkan pondasi ilmu dan motivasi yang kuat sebelum melanjutkan ke jenjang yang lebih tinggi.

Para narasumber juga menyepakati bahwa sebaiknya pengajaran CLIL mengikuti tren pembelajaran yang relevan untuk masa kini. Pengajaran sebaiknya memasukkan unsur teknologi dan game supaya siswa merasa termotivasi dan tertarik dengan pelajaran yang disampaikan. Pengajaran juga disarankan untuk menyertakan ilustrasi, gambar, icon yang sesuai minat anak sekolah dasar. Kurikulum pengajaran juga disesuaikan dengan tingkat matematika anak, di mana anak-anak diajarkan angka dan operasinya, bangun ruang, bangun datar yang mana mereka telah mengetahui istilah dalam Bahasa Indonesia.

Selain itu, para narasumber menyatakan bahwa pelatihan literasi matematika dalam Bahasa Inggris penting dan cukup diperlukan bagi siswa Indonesia karena umumnya kompetisi Internasional menggunakan soal-soal dalam Bahasa Inggris. Siswa perlu dibiasakan mengerti soal-soal dalam Bahasa Inggris dan dilatih untuk memecahkan secara analitis dan hal ini perlu dilatih semenjak bangku sekolah dasar.

Kemudian menurut narasumber, CLIL dapat memberikan manfaat ganda bagi siswa $\mathrm{SD}$, yaitu mereka mendapatkan pemahaman mata pelajaran dalam bahasa asing. CLIL juga dapat meningkatkan motivasi dan rasa percaya diri siswa. Siswa juga akan memiliki pemahaman interdisipliner yang baik, memiliki fleksibilitas yang lebih tinggi, terbiasa berpikir 
analitik dan kritis, dan secara jangka panjang. Hal tersebut akan mendukung siswa ke jenjang pendidikan selanjutnya dan mampu memberikan efek positif untuk performa siswa di tes internasional.

Untuk memperbaiki performa siswa Indonesia di bidang literasi matematika, baik dari segi pemahaman maupun performa dalam tes berskala internasional, dibutuhkan solusi baru yang perlu diterapkan di jenjang pendidikan dasar. Diharapkan dengan penerapan CLIL, kemampuan literasi matematika siswa dapat dikuatkan semenjak tingkat dasar. Penerapan CLIL akan lebih efektif dan menarik bila didukung dengan dengan aplikasi berbasis teknologi dalam pengajarannya, serta memasukkan unsur gamification. Dengan menerapkan pengajaran matematika dalam Bahasa Inggris dengan metode CLIL, siswa Indonesia akan lebih terbiasa dengan konsep pemahaman soal cerita dalam Bahasa Inggris, terbiasa menggunakan highorder thinking saat memecahkan soal matematika, memiliki minat yang lebih tinggi terhadap matematika dan Bahasa Inggris, mempersiapkan pondasi yang kuat untuk pelajaran matematika yang lebih kompleks di tingkat pendidikan lebih tinggi, serta menguatkan kemampuan literasi matematika berstandar Internasional. 


\section{DAFTAR RUJUKAN}

2nd Grade Mathematics: Solve Problems With Picture Graphs 1. (2019). Diambil kembali dari Khan Academy: https://www.khanacademy.org/math/cc-2nd-grade-math/cc-2ndmeasurement-data/cc-2nd-picture-graphs/e/solving-problems-with-picture-graphs1 ? modal $=1$

Collins, R. (2014). Skills for 21 st century: Teaching Higher-Order Thinking. Diambil kembali dari

http://www.curriculum.edu.au/leader/teaching_higher_order_thinking,37431.html?iss ueID $=12910$

Dinni, H. N. (2018). HOTS (High Order Thinking Skills) dan Kaitannya dengan Kemampuan Literasi Matematika. PRISMA, Prosiding Seminar Nasional Matematika, 1, 170-176. Diambil kembali dari https://journal.unnes.ac.id/sju/index.php/prisma/article/view/19597

Fehling, S. (2008). Language Awareness und blilingualer Unterricht: Eine komparative Studie. Ferreira, F., \& Morrison, F. J. (1994). Children's Metalinguistic Knowledge Of Syntactic Constituents: Effects Of Age and Schooling. Developmental Psychology, 30(5), 663678. doi:https://doi.org/10.1037/0012-1649.30.5.663

Ghazi, S. (2016). Concrete Operational Stage Of Piaget's Cognitive Development Theory: An Implication In Learning Mathematics. Diambil kembali dari http://www.gujr.com.pk/index.php/GUJR/article/view/133

Grum, U. (2012). Mündliche Sprachkompetenzen deutschsprachiger Lerner des Englischen. Entwicklung eines Kompetenzmodells zur Leistungsheterogenität.

Kandola, A. (2019). What To Know About Piaget's Stages Of Cognitive Development. Diambil kembali dari Medical News Todays: https://www.medicalnewstoday.com/articles/325030

Lasagabaster, D. (2008). Foreign Language Competence in Content and Language Integrated Courses. Diambil kembali dari http://benthamopen.com/ABSTRACT/TOALJ-1-30

Mahdiansyah, M., \& Rahmawati, R. (2014). Literasi Matematika Siswa Pendidikan Menengah: Analisis Menggunakan Desain Tes Internasional dengan Konteks Indonesia. Jurnal Pendidikan dan Kebudayaan, 20, 452-469. doi:10.24832/jpnk.v20i4.158

Marsh, D. (2002). CLIL/EMILE The European dimension. Actions, Trends, and Foresight Potential. Finland. Diambil kembali dari https://jyx.jyu.fi/bitstream/handle/123456789/47616/1/david_marsh-report.pdf

Marsh, D. (2013). Content and Language Integrated Learning (CLIL) A Development Trajectory. Diambil kembali dari https://helvia.uco.es/handle/10396/8689

Nikula, T. (2010). Language Use and Language Learning in CLIL Classrooms. John Benjamins Publishing Company. Diambil kembali dari https://books.google.co.id/books?hl=en\&lr=\&id=lT0zAAAAQBAJ\&oi=fnd\&pg=PA $105 \& d q=$ Nikula + CLIL+2010\&ots=FIINBEMhuO\&sig=SOZtKfKb_6NBwpH9p2TW eYoLNIE\&redir_esc $=\mathrm{y} \# \mathrm{v}=$ onepage $\& \mathrm{q}=$ Nikula\%20CLIL\%202010\&f $=$ false

OECD. (2019). PISA 2018 Results. Diambil kembali dari https://www.oecd.org/pisa/publications/pisa-2018-snapshots.htm 
OECD. (2019). PISA-Based Test For Schools Sample Test Items. Diambil kembali dari oecd.org/pisa/aboutpisa/PISA\%20for\%20Schools\%20sample\%20test\%20items.pdf

Piaget, J. (2003). Part I: Cognitive Development in Children--Piaget Development and Learning. Journal of Research in Science Teaching, v40 nS1 pS8-S18 2003. Diambil kembali dari https://eric.ed.gov/?id=EJ773455

Prochazkova, L. T. (2013). Mathematics for Language, Language for Mathematics. Diambil kembali dari https://files.eric.ed.gov/fulltext/EJ1108199.pdf

Rumlich, D. (2012). CLIL and Students' Linguistic Accuracy In Written English: Empirical Findings. CLIL: Research, Policy and Practice.

Surmont, J. (2016). The Effects Of CLIL On Mathematical Content Learning: A Longitudinal Study. Diambil kembali dari https://www.ceeol.com/search/article-detail?id=411489

Wakil, K., Qaisar, N., \& Mohammed, C. (2017). Enriching Classroom With Technology in the Basic School. 2(1). doi:http://doi.org/10.5281/zenodo.841925 
128 | DOI: 10.33479/klausa.v4i02.408 